https://doi.org/10.25143/socr.13.2019.1.104-109

\title{
Personas datu aizsardzības mērḳis un tiesiskā regulējuma vēsturiskā attīstība
}

\author{
Mg. iur. Agnese Reine-Vïtina \\ Rìgas Stradiṇa universitāte, Juridiskā fakultāte, Latvija \\ agnese.reine-vitina@rsu.lv
}

\section{Kopsavilkums}

Mūsdienās tiesības uz privāto dzīvi nepieciešamas ikvienā demokrātiskā sabiedrībā, un šo tiesību iekḷaušana konstitūcijā juridiski garantē fiziskas personas rīcības brīvību un vienlaikus arī citu - valsts pamatlikumā noteikto - cilvēka tiesību īstenošanu [5]. Personas datu aizsardzības institūts tika izveidots, izpratnes par tiesību uz personas privātās dzīves neaizskaramību saturu paplašinot 20. gadsimta 70. gados, kad vairāku Eiropas valstu valdības uzsāka informācijas apstrādes projektus, piemēram, tautas skaitīšanu u. c.

Informācijas tehnologiju attīstība ḷāva arvien vairāk informācijas par personām glabāt un apstrādāt elektroniski. Viena no tiesību problēmām bija informācijas vākšana par fizisku personu un tiesību uz privātās dzīves neaizskaramību ievērošana. Lai nodrošinātu privātās dzīves aizsardzību, atsevišḳas Eiropas valstis pēc savas iniciatīvas pieñēma likumus par datu aizsardzību. Pirmie likumi par personas datu aizsardzību Eiropā tika pieñemti Vācijas Federatīvajā Republikā, tad Zviedrijā (1973), Norvēǵijā (1978) un citur $[8,10]$. Ne visas valstis pieṇēma likumus par datu aizsardzību vienlaikus, tāpēc Eiropas Padome nolēma izstrādāt konvenciju, lai unificētu datu aizsardzības noteikumus un principus.

Atslēgvārdi: dati, fiziska persona, datu aizsardzība, cilvēktiesības, vēsturiskā attīstība.

\section{levads}

Mūsdienu tehnologiju attīstība un globalizācija ir mainījusi personas datu aizsardzības aktualitāti, izvirzot to par prioritāti. Lìdz ar Vispārīgās datu aizsardzības regulas stāšanos spēkā tika radīts jauns, vienots tiesiskais regulējums visā Eiropas Savienībā.

Raksta mērķis ir analizēt personas datu apstrādes tiesiskā regulējuma vēsturisko attīstību, lai varētu izprast personas datu apstrādes mērḳus un tiesiskā regulējuma 
piemērošanas īpatnības. Lai sasniegtu izvirzīto mērḳi, izmantotas tiesību normu interpretācijas metodes - vēsturiskā, gramatiskā, sistēmiskā un teleologiskā, kā arī vispārzinātniskās pētniecības metodes - analītiskā, aprakstošā un vēsturiskā metode.

\section{Personas datu tiesiskā regulējuma vēstures galvenie pieturpunkti}

Eiropas Padomes ieguldījums privātās dzīves aizsardzības tiesību nostiprināšanā ir īpaša Eiropas Padomes 1981. gada 28. janvāra Konvencija Nr. 108 par personu aizsardzību attiecībā uz personas datu automātisko apstrādi (turpmāk tekstā - Konvencija). Konvencijas preambulā ir noteikts, ka vēlams paplašināt katras personas tiesību un pamatbrīīibu aizsardzību, it īpaši tiesību uz privātās dzīves neaizskaramību, ņemot vērā automātiski apstrādātu personas datu arvien pieaugošo plūsmu pāri robežām, un Konvencijas dalïbvalstīm tika izvirzìtas konkrētas prasības attiecībā uz personas datu tiesisko aizsardzību [8, 11]. Konvencijas tvērums attiecas uz Eiropas Padomes dalībvalstīm, kuras parakstijjušas un ratificējušas šo Konvenciju, kā arī uz četrām valstīm, kuras nav Eiropas Padomes dalībvalstis, taču, pamatojoties uz uzaicinājumu, parakstijja un ratificēja Konvenciju (Maurīcija, Senegāla, Tunisija un Urugvaja) [9].

Vēl pagājušā gadsimta 90. gados visās Eiropas Savienības (turpmāk tekstā - ES) dalībvalstīs nebija speciālu likumu par datu aizsardzību, bet esošie likumi paredzēja diezgan atšķirīgus noteikumus. Viena no lielākajām problēmām bija tā, ka ES dalībvalstu likumos par datu aizsardzibu tika noteikts aizliegums nodot personas datus uz citu valsti, ja tajā nav atbilstošas aizsardzības $[8,11]$.

Māstrihtas līguma F 2. pantā tika noteikts, ka ES respektēs pamattiesības, kas garantētas Cilvēktiesību konvencijā, dalībvalstu konstitucionālajās tradīcijās un Savienības vispārīgajos principos. Pamatojoties uz to, kā arī nolūkā ievērot vienotā tirgus principu 1995. gada 24. oktobrī ES tika pienemta Eiropas Parlamenta un Eiropas Padomes Direktīva 95/46/EK "Par personas aizsardzību attiecībā uz personas datu apstrādi un to brīvu apriti” [2]. Šajā Direktīvā paredzēts, ka ES dalībvalstīm līdz 1998. gada 24. oktobrim jāpiennem atbilstoši normatīvie akti, ar kuriem tiek reglamentēta personas datu apstrādes kārtỉba $[8,11]$.

Eiropas Savienība 2000. gada 7. decembrī pieṇēma Eiropas Savienības Pamattiesību hartu. Hartas 8. pantā paredzēts, ka ìpaši tiek izdalītas personas tiesības uz datu aizsardzību. Citos starptautiskajos dokumentos un Satversmē tās ietvertas privātās dzīves jēdzienā un tādēl netiek atsevišḳi izdalìtas:

- ikvienai personai ir tiesības uz savu personas datu aizsardzỉbu;

- personas dati jāapstrādā godprātīgi, noteiktiem mērḳiem un ar attiecīgās personas piekrišanu vai ar citu likumigu pamatojumu, kas paredzēts tiesību aktos;

- ikvienam ir pieejas tiesības datiem, kas par viṇu savākti, un tiesības ieviest labojumus šajos datos;

- atbilstību šiem noteikumiem kontrolē neatkarīga iestāde. [4] 
Tāpat kā Satversmes 96. pantā, arī Cilvēka tiesību un pamatbrīiību aizsardzības konvencijas 8. pantā [1] ir noteiktas personas tiesības uz privātās dzīves neaizskaramību. Ar privātās dzīves neaizskaramību tiek saprastas arī personas tiesības uz datu aizsardzību [5].

Tehnologiju straujā attīstība un pieaugošā tiesu prakse, skaidri norādỉja uz nepieciešamību pieñemt jaunu starptautisku tiesisko regulējumu attiecībā uz personas datu apstrādi. Iepriekšējais regulējums bija Eiropas Parlamenta un Padomes Direktīva 95/46/EK (1995. gada 24. oktobris) par personas aizsardzību attiecībā uz personas datu apstrādi un šādu datu brīvu apriti (turpmāk tekstā - Direktīva). Nemot vērā, ka Direktīva tika pieñemta 1995. gadā, skaidri saprotams, ka tās tvērums neatbilst mūsdienu datu apstrādes procesiem un nenodrošina personas datu nepieciešamo aizsardzību.

2012. gada 25. janvārī Eiropas Komisija ierosināja visaptverošu 1995. gada ES datu aizsardzības reformu, lai nostiprinātu tiesības uz privātumu tiešsaistē un stimulētu Eiropas digitālo ekonomiku. Jauna ES datu aizsardzības regulējuma ieviešanas mērkis bija panākt vienveidīgu datu aizsardzības normatīvā regulējuma attīstību gan ES, gan nacionālajā līmenī.

Jaunais regulējums, tehnologiskais progress un globalizācija ir dziḷi mainījuši veidu, kā tiek vākti personas dati, kā notiek piekḷuve tiem un kā dati tiek izmantoti, turklāt 27 ES dalībvalstis 1995. gada noteikumus ir îstenojušas atšḳirīgi, tāpēc arī to izpilde ir notikusi dažādi. Vienotam tiesību aktam vajadzēja novērst pastāvošo sadrumstalotību. "Pirms 17 gadiem mazāk nekā $1 \%$ eiropiešu lietoja internetu. Mūsdienās ik sekundi notiek milzīga personas datu apjoma nosūtišana un apmaiṇa starp kontinentiem un visā pasaulē," sacīja Viviāna Redinga, ES tieslietu komisāre un Komisijas priekšsēdētāja vietniece [10].

2012. gada 7. martā Eiropas datu aizsardzības uzraudzītājs (turpmāk tekstā - EDAU) sniedza atzinumu par datu aizsardzības reformas paketi, kurā ietverti detalizēti komentāri par priekšlikumiem. EDAU atzinumā pauda šādu viedokli: "EDAU atzinīgi vērtē ierosināto regulu, jo tā ir liels solis uz priekšu Eiropas datu aizsardzības jomā. Ar ierosinātajiem noteikumiem tiks nostiprinātas fizisku personu tiesības un paredzēta lielāka pārziṇu atbildība par veidu, kādā tie rīkojas ar personas datiem. Turklāt ierosinātajā regulā faktiski tiek paplašinātas valstu uzraudzības iestāžu (atseviški un kopā) pilnvaras un uzdevumi. EDAU pauž īpašu gandarījumu par to, ka ierosinātais vispārīgu datu aizsardzības noteikumu piemērošanas instruments ir regula. Ierosinātā regula būtu tieši piemērojama dalībvalstīs un novērstu daudzus sarežǵìjumus un neatbilstības, ko izraisītu dažādie îstenošanas tiesību akti, kas patlaban ir spēkā dalībvalstīs. EDAU uzsver, ka, lai gan tiesībaizsardzības jomā ir vajadzīgi īpaši noteikumi, ikviena atkāpe no vispārējiem datu aizsardzības noteikumiem ir pietiekami jāpamato, nodrošinot pienācīgu līdzsvaru starp sabiedriskajām interesēm tiesībaizsardzības jomā un pilsoṇu pamattiesībām.” [11]

Straujā tehnologiju attīstība un globalizācija ir radījusi jaunas problēmas personas datu aizsardzībā. Personas datu vākšanas un apmaiṇas apjoms ir būtiski pieaudzis. Tehnologiijas lauj gan privātām uzṇēmējsabiedrībām, gan publiskām iestādēm vēl nepieredzētā apjomā savas darbības mērḳiem izmantot personas datus. Fiziskas personas 
aizvien biežāk piel̦auj personiska rakstura informācijas publisku un globālu pieejamību. Tehnologiijas ir pārveidojušas gan ekonomiku, gan sociālo dzīvi, un tām arī turpmāk būtu jāuzlabo personas datu brīva aprite Eiropas Savienībā un nosūtišana uz trešajām valstīm un starptautiskām organizācijām, vienlaikus nodrošinot personas datu augsta līmeņa aizsardzību [3]. Nekontrolētas datu apstrādes sekas var būt datu subjektu tiesību uz privāto dzìvi aizskārums, kas savukārt var novest pie liela prasību skaita pieauguma tiesās attiecībā uz personas datu aizsardzības pārkāpumiem.

Tehnologiskā attīstība un cilvēku paradumu maiṇa skaidri norādỉja uz jauna regulējuma aktualitāti un nepieciešamību. Tā tvērumam vajadzēja atbilst datu apstrādes mūsdienu principiem, paradumiem un sistēmām, kā arī nodrošināt apstrādājamo / uzglabājamo datu drošỉbu.

Direktīvas mērki un principi joprojām ir spēkā, taču tā nespēja novērst datu aizsardzības isstenošanas sadrumstalotỉbu ES, juridisko nenoteiktîbu un sabiedrībā plaši izplatîtu uzskatu, ka pastāv ievērojams fizisku personu datu aizsardzības risks, jo īpaši tiešsaistes aktivitātēs [3, preambulas 9. punkts]. Direktīva pilnībā nesasniedza mērḳi tieši juridiskās formas dēḷ. Direktīvā tika norādīti tikai ES dalībvalstu kopīgie mērḳi, katrai dalībvalstij nacionālā līmenī sniedzot iespēju mērḳus iestrādāt, tos korigêejot un pielāgojot atbilstoši dalībvalsts vajadzībām. Šāda plaša un brīva Direktīvas interpretācijas iespēja veicināja to, ka ES dalïbvalstīs neradās vienots datu aizsardzības regulējums.

2016. gada 27. aprīli tika pien,emta Eiropas Parlamenta un Padomes Regula (ES) 2016/679 par fizisko personu aizsardzību attiecībā uz personas datu apstrādi un šādu datu brīvu apriti un ar ko atcel Direktīvu 95/46/EK (Vispārīgā datu aizsardzības regula), turpmāk tekstā - Datu aizsardzības regula. Pieṇemot jauno tiesisko regulējumu tieši regulas formā, tika nodrošināta vienota izpratne un vienots tiesiskais regulējums visās ES dalībvalstīs. Pretstatā Direktīvai Datu aizsardzības regula ir juridiski saistoša un tieši piemērojama visās ES dalībvalstīs, un tas nozīmē, ka Datu aizsardzības regulas nosacījumi nav interpretējami un iestrādājami dalībvalstu nacionālajos tiesību aktos, veicot savas korekcijas. Dalībvalstis drīkst iestrādāt Datu aizsardzības regulas prasības arī nacionālajos tiesību aktos, tikai tiešā veidā pārnesot regulas prasības vai tās precizējot attiecībā uz nacionālo piemērošanu.

Datu aizsardzības regulas preambulas 4. punktā ir teikts, ka personas datu apstrāde būtu jāveido tā, lai tā kalpotu cilvēkam. Tiesības uz personas datu aizsardzību nav absolūta prerogatīva, tās ir jānnem vērā saistībā ar to funkciju sabiedrībā un jālīdzsvaro ar citām pamattiesībām saskaṇā ar proporcionalitātes principu. Šajā regulā ir ievērotas visas pamattiesības, brīvības un principi, kas atzīti hartā un ietverti līgumos, jo īpaši privātās un gimenes dzìves, mājokḷa un sazinnas neaizskaramība, personas datu aizsardzỉba, domu, pārliecības un ticības brīvība, vārda un informācijas brīvība, darījumdarbības brīvība, tiesības uz efektīvu tiesību aizsardzību un taisnīgu tiesu un kultūru, kā arī reliǵiju un valodu daudzveidíba [3].

Datu aizsardzỉbas regulas pieņemšanai ir liela nozīme, un tā iesāk būtisku attīstības posmu personas datu aizsardzības tiesiskajā regulējumā. Līdz ar tās ieviešanu, personas 
datu aizsardzība ir kḷuvusi par vienu no prioritātēm visiem personas datu apstrādātājiem un uzglabātājiem.

\section{Secinājumi}

Personas datu aizsardzība un tās tiesiskais regulējums ir attīstījies kopš 20. gadsimta 70. gadiem, kad aizvien biežāk informācija tika glabāta elektroniskā veidā. Personas datu aizsardzības tiesiskais regulējums Eiropā tika ieviests pakāpeniski, tādējādi nebija vienotas izpratnes gan par šāda regulējuma nepieciešamību, gan par datu apstrādes principiem. Vēsturiskās attīstības gaitā vairākkārt tika izstrādāti starptautiski tiesību akti, lai nodrošinātu vienotu regulējumu personas datu aizsardzībai, taču šie regulējumi nesasniedza mērḳi un nespēja novērst sadrumstalotību attiecībā uz datu apstrādes principiem. Analizējot datu apstrādes tiesiskā regulējuma attīstības gaitu, secināms, ka ieviestā Datu aizsardzības regula pēc savas juridiskās formas un izstrādātajiem noteikumiem nodrošina vienotu pieeju personas datu apstrādes principiem un to nodrošināšanai.

\section{Objective of Protection of Personal Data and Historical Development of Legal Framework}

\section{Abstract}

Nowadays, the right to privacy is indispensable in every democratic society and inclusion of such rights in the constitution, guarantees legally freedom of action of a natural person and, simultaneously, implementation of other human rights established in the fundamental law of the state. The institute of personal data protection was established by expanding the understanding of the content of the right to privacy in the 70's of the $19^{\text {th }}$ century, when the government of several European countries initiated information processing projects, such as population census etc. For the development of information technology, more and more information on persons was kept and processed in electronic form. One of the legal problems was gathering of information on natural persons and the right to privacy. In order to ensure the protection of privacy, separate European countries, on their own initiative, established a law on data protection. The first laws on the protection of personal data in Europe were established in the Federal Republic of Germany, then in Sweden (1973), Norway (1978) and elsewhere. Not all countries adopted laws on data protection at the same time, so the Council of Europe decided to elaborate a convention to unify data protection rules and principles.

Keywords: data, natural person, data protection, human rights, historical development. 
Agnese Reine-Vìtina. Personas datu aizsardzības mērḳis un tiesiskā regulējuma vēsturiskā attīstība

\section{Avoti un literatūra}

\section{Tiesību akti}

1. Cilvēka tiesību un pamatbrīvību aizsardzības konvencija: starptautisks dokuments: pieṇemta 04.11.1950. un stājās spēkā 27.06.1997. Latvijas Vēstnesis. 143/144(858/859), 13.06.1997.

2. Eiropas Padomes 24.10.1995. Direktīva 95/46/EK par personas aizsardzību attiecībā uz personas datu apstrādi un to brīvu apriti. Eiropas Savienības Oficiālais Vēstnesis. L281/31, 23.11.1995.

3. Eiropas Parlamenta un Padomes Regula (ES) Nr. 2016/679 (27.04.2016.) par fizisko personu aizsardzību attiecībā uz personas datu apstrādi un šādu datu brīvu apriti un ar ko atcel Direktīvu 95/46/EK (Vispārīgā datu aizsardzības regula): starptautisks dokuments. Eiropas Savienības Oficiālais Vēstnesis. L 119/1, 04.05.2016.

4. Eiropas Savienības Pamattiesību harta 2012/C 326/02: starptautisks dokuments. Eiropas Savienības Oficiālais Vēstnesis. C326/391, 26.10.2012.

5. Latvijas Republikas Satversme: Latvijas valsts likums: pieṇemta 05.02.1922. un stājās spēkā 07.11.1922. Latvijas Vēstnesis. 43, 01.07.1993.

\section{Tiesu prakse}

6. Satversmes tiesas 12.05.2016. spriedums lietā Nr. 2015-14-0103 "Par DNS nacionālās datubāzes izveidošanas un izmantošanas likuma 1. panta 2. un 6. punkta, 4. panta, 10. panta, 18. panta pirmās daḷas, kā arī Ministru kabineta 2005. gada 23. augusta noteikumu Nr. 620 “DNS nacionālajā datubāzē iekḷaujamo ziṇu sniegšanas, kā arī biologiskā materiāla un biolog̣iskās izcelsmes pēdu izṇemšanas kārtība" 2. un 13. punkta tiktāl, ciktāl tie attiecas uz aizdomās turētajām personām, atbilstību Latvijas Republikas Satversmes 96. pantam”. Latvijas Vèstnesis. 92(5664), 13.05.2016.

\section{Literatūra}

7. Morgan, R., Boardman, R. 2012. Data protection strategy. Implementing data protection compliance. London: Sweet\&Maxwell Limited.

8. Ruksers, M. 2008. Fizisko personu datu aizsardzības likuma komentāri. Rīga: SIA "E-sabiedrības risinājumi”.

\section{Interneta resursi}

9. Chart of signatures and ratifications of Treaty 108. Council of Europe. Iegūts no: https://www. coe.int/en/web/conventions/full-list/-/conventions/treaty/108/signatures?p_auth=nQZzeuBp [sk. 01.05.2019.].

10. Eiropas Komisijas paziņojums presei. Komisija ierosina visaptverošu datu aizsardzības noteikumu reformu, lai palielinātu lietotāju iespējas kontrolēt savus datus un samazinātu izmaksas uzṇēmumiem. European Commission. Iegūts no: https:/europa.eu/rapid/press-release_IP-12-46_ lv.htm [sk. 03.08.2019.].

11. Opinion of the European Data Protection Supervisor on the data protection reform package. European Data Protection Supervisor. Iegūts no: https:/edps.europa.eu/sites/edp/files/publication/12-03-07_edps_reform_package_en.pdf [sk. 22.07.2019.]. 